\title{
Nietzsche Versus Paul, by Abed Azzam
}

Insurrections: Critical Studies in Religion, Politics, and Culture | New York: Columbia University Press, 2015 | xx + 209 pages | ISBN: 978-0-23I-I6930-I (hardcover) \$90.00; ISBN: 978-0-23 I-I693 I-8 (softcover) \$30.00; ISBN: 978-0-23 I-538978 (ebook) \$29.99

Hampered by prose that is dense, sometimes turgid (and occasionally, for a run of paragraphs, often pages, the unkind might say, obscurantist), one is gripped

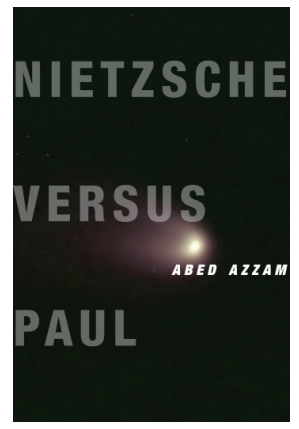
by a strong temptation to suspect that Abed Azzam's attempt to dislodge 
the time-honored reading of Nietzsche's (principally) philosophical anti-Plato stance, and to shunt it onto an Antichrist theological track located deep in the heart of orthodox Christian territory, is bound to fail. But perhaps this sort of premature response springs from an impatient, superficial reading? But why undertake such a difficult project in the first place if the "essential Nietzsche," on Azzam's own reading, is "impossible" to find? (xiii). Because rightly or wrongly, Azzam, convinced that Nietzsche's intentions are not simply driven by a Dionysian philosophy, claims to have discovered "an open historical horizon of Christianity" in the philosopher's works which "must challenge the prevailing view" (I47).

Abed Azzam's aims are as sweeping as they are ambitious. On the one hand, Nietzsche Versus Paul claims to be "a study of the Christian embrace of Nietzsche's sought-after truth that ends in its obliteration" (xii). On the other hand, the procedure which governs that study is shaped "as a reconstruction of the Nietzschean history of Christianity ... revolving around the question (of pessimism) about the meaning of suffering" with a view to:

(I) reintegrating into the discourse the "largely neglected" Nietzsche-Paul relationship (xvi);

(2) redressing the perceived oversight of Nietzsche's treatment of Christianity and Judaism;

(3) establishing the premise that the Nietzsche-Antichrist plumb line is far more important than "the anti-Platonic one" (xv);

(4) exposing "how Nietzsche's understanding of Socrates is one guided by his reading of Paul" (xix);

(5) expounding Nietzsche's critique of Modernity, famously its focus on the principle of "self-preservation" (xx).

Azzam appears to be confident that he has achieved his aims, and in addition claims:

(I) to have "located Nietzschean thinking in the bosom of Pauline theology, insofar as these... three parts match its triangle consisting of Christ, the Antichrist, and the Katechon" ( 146 ); 
(2) to have confirmed his understanding of the mutual cancellation of Heidegger's and Deleuze's readings of Nietzsche because both "delimit" themselves "to the horizon of the history of philosophy, or Nietzsche and the antiPlato" (I 47);

(3) and finally, to have successfully defined the significance of the Greek Dionysian origin in Nietzsche's thinking in the context of Christian/Pauline thinking, citing Karl Löwith's understanding of Nietzsche's "religiosity as being Christian and un-Greek" - while at the same time decrying Löwith's condemnation of Nietzsche's "departure from the path of philosophy and his taking of the Christian path," and Löwith's insistence on making "philosophy a constant and Christian variable" (I49).

Azzam is aware of the implications of such revisionist claims, but perhaps not the wrestling with mutually contradictory insights that comes with them, and more, the debates that will ensue over the notion that "Nietzsche's atheism is Christian and not Greek" (I 50 ). Intriguing as this assertion might be, his cause is not helped by the ambiguity and opacity of his conclusions (I 50 ):

(I) Nietzsche's Christian legitimization of the modern Antichrist brought him to the idea of the legitimacy of the origin as such;

(2) Nietzsche's innocent "I am" has the original faith of Abraham as its constitutive model;

(3) Insofar as Nietzsche's visible horizon could not extend beyond the repressed Greek Dionysus, Nietzsche becomes a questionable Dionysian philosopher.

In the end, we are left with these questions: has Azzam furthered a line of scholarship that emphasizes the significance of Paul for understanding Nietzsche's project? (or more pressingly) has he added anything new to the Nietzsche-Pauline contra? and, finally, has he convincingly argued his revisionist theses?

My reaction to Nietzsche Versus Paul oscillates from a feeling of strong irritation at times and deep misgivings, to an expectation that in amongst the opaqueness of its delivery lies something provocative, something that might 
even confirm my own revisionist understanding of Nietzsche. My intuition about this kept encouraging a more patient reading, for somehow there was a sense that here were the beginnings of a groundbreaking investigation, even though there were initial hurdles to overcome, as the following list of reservations illustrate.

First, Azzam draws attention to what might be called Nietzsche's tease provocation that, although the philosopher barely even knows himselfnever mind anyone else ("Es ist schwer zu erkennen, wer ich bin"), it nevertheless allows for the possibility that a "genius" might in a hundred years arise who really "knows" humankind and be (cap)able [inferred] of digging Mr F. N. out of his grave ("irgend ein Genie von Menschenkenner, welches Herrn F. N. ausgräbt": $K G B, 3.3$, Briefentwurf an Heinrich von Stein [Mitte März, I 885 ] 27). For me it was more than a tease: it is a provocation to follow Nietschze's's clues to a kind of El Dorado discovery of the missing pieces in his project, his Rätzel. So right from the start, Azzam signals that he is totally aware of the impossibility of such an enterprise, even if he is inspired and excited by it. Though paradoxically he has Heidegger and Deleuze agreeing "that an essential-Nietzsche ought to be sought" (xiv), possibly to strengthen his case against them as "partial readings" (xv). His categorical negation of their theses ("neither can be said to represent the essential-Nietzsche") and his argument by assertion as fact ("For the undeniable fact remains that the negative standpoint which Nietzsche's writings take is primarily that of the Antichrist and not that of the anti-Plato"; xv), however, places Azzam in a vulnerable position with quite some convincing to do. He goes on to say that "the possibility of fleshing out the essential Nietzsche cannot be made unless Nietzsche's Antichrist is first examined" (xv), so imposing even greater demands, and further raises the question as to why there should be this "shift away from philosophy to the history of Christianity" (xv).

Second, Nietzsche Versus Paul contends that because Nietzsche speaks of a "Dionysus versus the Crucified" that this must necessarily rule out the significance of the strong "pagan philosophical" roots going back to Plato and Socrates, something that surely must be contested when two other equally breath-taking assertions taken out of context from Nietzsche - that "Plato becomes a Christian before Christianity," and that Hegel becomes a Katechon (delayer) (xv) are also touted as factually true of Nietzsche's position.

Third, Nietzsche Versus Paul (at a time when the dialogue between theology and philosophy seems to be opening up) is determined to reignite the old controversies that followed in the wake of their divorce and to reintroduce 
the cloud of misunderstanding under which both disciplines have labored for a number of centuries, by his dismissive comments regarding philosophy's limited horizon. Such a stance is unhelpful.

Fourth, Azzam claims that, for Nietzsche, "the genuine character of Modernity ... [rests] on its discontinuity with Christianity" (xx), when the weight of scholarly opinion seems to lie with the conviction that Nietzsche's project defines Modernity as infected by the ressentiment of institutional Christianity. But, as a consequence of casting Nietzsche in the role of contesting within a theological and Christian framework, it is in Azzam's interest to "prove" that Nietzsche somehow sides with Christianity against Modernity's "idea of its own worldliness... grounded in the principle of self-preservation" (xx). And when Azzam adds to this the notion that somehow Nietzsche also sees Hegel as the delayer (Katechon) of atheism, while there may be some truth there, does this necessarily mean that Nietzsche's views correspond with $\mathrm{St}$ Paul's view of the Antichrist as understood from within a Christian context?

Azzam is certainly onto something by insisting on more of a "Christian" perspective than has often been admitted with Nietzsche-although even here there is a substantial body of work that would endorse it. Some authors and titles include: Giles Fraser, Redeeming Nietzsche: On the Piety of Unbelief; Tyler Roberts, Contesting Spirit: Nietzsche, Affirmation, Religion; Bruce Ellis Benson, Pious Nietzsche: Decadence and Dionysian Faith; Lippitt and Urpeth (eds.), Nietzsche and the Divine; Alistair Kee, Nietzsche Against the Crucified; Craig Hovey, Nietzsche and Theology; Stephen Williams, The Shadow of the Antichrist. However, caution is to be urged as to how this might be executed.

While agreeing that Nietzsche's audience is Christian, and his revisionist project arises from deep within a Christian theological framework, ${ }^{3}$ I don't believe it is necessary in so doing that we have to ditch philosophy or deny its Greek pagan antecedents by painting it over with a Christian veneer.

This review is not the occasion for an in-depth analysis of Azzam's revisionist claims, but certainly these claims will demand the close attention of those writing on Nietzsche's project in the future-as certainly will be the

\footnotetext{
${ }^{3}$ See Lucy Huskinson, An Introduction to Nietzsche (Baker Academic, 2009), xvii: "Nietzsche's target audience is Christian, and... his writings intend to provoke Christians with a timely wake-up call. In particular, it highlights those aspects of Nietzsche's critique of Christianity that expose problems within Christian discipleship, such as the common inability among Christians to comprehend the meaning of faith, and to realize how excruciatingly difficult and "serious it is both to live an authentically Christian life and to facilitate the life-enhancing force of Christianity."
} 
case for this reviewer. However, a general critique can be offered to pique the appetite of the casual and scholarly reader.

There are two central questions I would direct at Azzam's mind-bending work: why does it strive so passionately to situate Nietzsche within a "Christian" context; and why does it so vehemently oppose philosophy, when Azzam's exercise clearly is a struggle to make something fit that doesn't seem to fit, and more seriously, might actually distort Nietzsche's (philosophical, psychological and cultural) project in the process?

Azzam, naturally, would defend his thesis by arguing that it arises from Nietzsche's own words and declarations, which in fairness Azzam cites often and in detail. And certainly there is much to support his revolutionary claims in as far as the philosopher/psychologist is forever breaking the rules: behaving as a philosopher and so offending the philology establishment; then flouting the philosophers by "inventing" psychology; thumbing the nose at the Christian institutional Church of his day (Protestant and Lutheran and Catholic) together with the political institutions that are embedded with it; and indeed, turning his back on the academic establishment in general by becoming a "gypsy" thinker of no fixed abode. But the very nature of the constantly shifting sand of Nietzsche's positional thinking itself should be sufficient warning not to take any of the philosopher's pronouncements at face value, certainly not to take them out of context, with the even more urgent caveat, to account for the tone, style, and genre with which any of his declarations are made - not to mention rhetoric. Which, fair to say, Azzam rarely does. But then again, Tracy B. Strong may well be right to point out this is Nietzsche's problem as much as it is any commentator's insofar as Nietzsche's "rhetorical excesses" raise "the question of the responsibility of a writer for the unintended consequences that his writing permits" (Friedrich Nietzsche, International Library of Essays in the History of Social and Political Thought (Ashgate, 2009), xvii).

Nidesh Lawtoo, The Phantom of the Ego (Michigan State University Press, 2013) and Christa Acampora, Contesting Nietzsche (The University of Chicago Press, 20I 3) — both reasonably representative of sound Nietzschean scholarshipwould vigorously contest the assumptions upon which Azzam's premises are based. Their philosophical, psychological, cultural, and rigorously historical contextual approaches expose the shaky foundations upon which Azzam builds. Lawtoo's treatment locates the Nietzsche-Plato axis in the context of Nietzsche's discussion of Modernity. It goes something like this. There is a sickness of mind at the heart of modernism created by ressentiment. It is a 
Platonic and Wagnerian sickness: "a phantom of the ego," in fact a collective phantom which robs us of our authenticity, our individuality, our affirmation of life, our hope and our grip on reality generally. The central problem with which Nietzsche grapples is how to sustain a "pathos of distance" which prevents us from slipping into "self-dissolution" and the nightmare of "non being" and a loss of purpose, one of "being and not being a subject." Far from blunting his analysis, the inclusion of himself in Modernity's pathology, Lawtoo claims, sharpens Nietzsche's critical lens. Indeed, Lawtoo posits that Nietzsche's personal experience of Bayreuth leads him to the conclusion that Wagner and modernity are two sides of the same coin, the Bayreuth theatrical circle being the crucible in which Nietzsche's insights are forged. In sum, Lawtoo's Nietzsche is concerned with the critique of modernism which has little to do with Azzam's Pauline "Antichrist" as he explains it; though from this reviewer's perspective, the notion could be customized to accommodate the arrogance, deception, and accusatory spirit of the biblical Antichrist.

Thus, in sum, Nietzsche's preoccupation with Wagner and Plato from Lawtoo's perspective is profound, one from which it would be seemingly impossible to "shift" into something like a purely Antichrist justification based on Pauline theology. Yes, the Antichrist is important in the Nietzsche project; yes he would have been aware of St Paul as the "revaluator" of noblemorality-but none of these either individually or as a whole cancel out the vital connection with Dionysus, which Lawtoo defines as also being part and parcel of Modernity's neurosis. Lawtoo explains: "The Dionysian mimesis he had celebrated in his youth with Wagner, contra Plato, he now condemns as a sickness with Plato contra Wagner. This revaluation in Nietzsche's preoccupation with mimesis during his later period involves a shift of emphasis from aesthetics to morality" (Lawtoo, 65).

When we place Azzam's claims alongside Acampora's version of Nietzsche's contestation with Paul in the context of the agon once again we are caused to wonder about the stability and even the validity of Azzam's project. Under the section title, "Fighting to the Death: the Agonies Of Pauline Christianity," Acampora states that Nietzsche's attack on Pauline Christianity is an outgrowth of his struggle with Socrates, that in fact his case against Paul is like his case against Socrates in many ways, "except that Paul lacks some of Socrates's redeeming qualities," and claims that Paul remains Saul as a persecutor of God (Acampora, I I 2). Acampora goes on to note that "Nietzsche depicts [Pauline?] Christianity as complicit in bringing about its own destruction insofar as it sets up a contest as central to the meaning of what it 
is to be a good Christian, but the goal (eradicating what makes one a human being) undermines the very possibility of being a legitimate contestant for vying for the meaning of human existence" (Acampora, I I 5 ). In essence, Acampora argues that Nietzsche's reasons for "contesting" with Paul is that he illustrates a mode of destructive competitiveness that defeats the positive purposes of the agon, which is to ensure the health of the individual and the community. She notes that the words which Nietzsche uses for St Paul's struggle are drawn straight out of Luther's Bible, Wettkampf, and Kampf. In effect Acampora posits that Nietzsche sees Paul as heralding Christ's agonies which are actually not inherent in the original symbol of the figure of the Jesus of "glad tidings." And that Paul invests those agonies with a particularly potent significance that serves to elevate his own status. She goes on to say that in Nietzsche's account of "the genuine history of Christianity," he distinguishes Christian doctrine and dogma from the life of Christ: "in truth there was only one Christian and he died on the cross. The 'evangel' died on the cross. What has been called 'evangel' from that moment was actually the opposite of that which he lived: 'ill tidings,' a dysangel!" (Der Antichrist, 39).

Consequently, while it is possible to see that he was aware of Paul, it is quite impossible to fathom how Nietzsche, at least in Lawtoo's and Acompara's readings of him, would emulate Paul as a model. But maybe here is the rub: that as Nietzsche himself admitted, "The greatest part of our being is unknown to us.... We have a phantom of the 'ego' in our heads, which determines us many times over" (cited by Lawtoo from Nietzsche's Nachlass, I).

There is much to be gleaned from Azzam's work, for which it is to be prized, particularly its discovery of "an open historical horizon of Christianity" in Nietzsche's works which "must challenge the prevailing view" (I47), but perhaps not quite in the exact way Azzam was hoping for. For all of the difficulties both in terms of accessibility and argument, Nietzsche Versus Paul is worth the effort. I commend it as a challenging and intriguing exposition.

Nikolai Blaskow

Bangor University 